ANALELE UNIVERSITĂTII DIN BUCUREȘTI - SERIA DREPT

\title{
Vinovăția în cazul infracțiunilor comise de persoana juridică
}

Cristina Cucoaniș

Master Științe Penale

Facultatea de Drept, Universitatea din București

"Les personnes morales n'ont ni chair ni sang, pourtant elles ont des organes. Elles n'ont pas de sentiments, pourtant elles ont une volonté. Elles sont invisibles, pourtant elles agissent et peuvent même se voir reprocher leur inaction $»^{1}$

Rezumat: Prezentul material își propune să abordeze succint una dintre cele mai stridente probleme născute în legătură cu răspunderea penală a persoanei juridice, anume determinarea formei de vinovăție a acesteia, cu referire la raportul dintre vinovăția persoanei juridice și cea a persoanei fizice și oferirea unor aspecte de luat în considerare atunci când se analizează aceste elemente. Totodată, lucrarea atrage atenția asupra riscurilor la care persoana juridică se poate expune dacă nu își duce la îndeplinire obligațiile de control și de supraveghere.

Cuvinte cheie: răspundere penală, persoană juridică, formă vinovăție, control, supraveghere.

\section{Criminal intent in case of crimes committed by a moral person}

Abstract: The following paper aims to briefly address one of the most pressing issues arising in connection with the criminal liability of the legal person, namely the determination of its form of criminal intent, with reference to the relationship between the criminal intent of the legal person and that of the individual along with the provision of aspects to be taken into consideration when analyzing such elements. At the same time, the paper draws attention to the risks to which the legal person may be exposed if it does not fulfill its control and supervision obligations.

Key words: criminal liability, legal person, criminal intent, control, supervision.

\footnotetext{
1 În traducere liberă "Persoanele juridice nu au nici carne, nici sânge, dar au organe. Nu au sentimente, dar au voință. Sunt invizibile și totuși acționează, putându-li-se reproșa inacțiunea lor". A se vedea Emmanuel Dreyer, în François Esclatine, Personne morale en procès, cherchez la personne physique..., în Supplément de la Lettre des Juristes d'Affaires $n^{\circ} 1413$ din 23 septembrie 2019, №62, o. 14, disponibil la adresa https://www.perseusweb.fr/nar6/uploads/lja62-mag-web.pdf, accesată în data de 30.10.2021.
} 


\section{SCURTE CONSIDERAṬII INTRODUCTIVE}

Dreptul penal este ramura de drept care a avut întotdeauna o puternică componentă imagistică, în sensul că spețele ce aparțin de acest domeniu au la bază o desfășurare a evenimentelor ce poate fi reprodusă mintal cu o oarecare ușurință de către ascultătorul lor. Acest caracter vizual al problemelor de drept penal le face să pară accesibile și ușor de analizat. Cum se prezintă însă situația atunci când cel care a săvârșit infracțiunea nu a ridicat un deget? Nu este vorba despre faptul că nu și-a dat silința, ci despre faptul că, în realitate, chiar nu avea vreun deget.

Cu toate că s-a scurs o perioadă semnificativă de timp de la instituirea răspunderii penale generale a persoanei juridice prin Legea nr. 278/2006 pentru modificarea şi completarea Codului penal, precum şi pentru modificarea şi completarea altor legi ${ }^{2}$, aceasta pare a fi un concept căruia i se opun încă dificultăți de înțelegere.

De-a lungul timpului a fost greu de imaginat cum persoana juridică poate în primul rând săvârși o infracțiune, ulterior născându-se diverse probleme de încadrare a elementelor ce țin de răspunderea sa în instituțiile deja existente ale dreptului penal.

Atitudinea ce se impune a fi îmbrățișată este cea de contenire a combaterii existenței răspunderii penale a persoanei juridice în sine și de aplecare doctrinară asupra îndepărtării obstacolelor ce se arată ${ }^{3}$.

Prezenta lucrare își propune să analizeze una dintre aceste probleme, anume cum se stabilește forma de vinovăție cu care persoana juridică acționează în desfășurarea activității sale infracționale și cum se conciliază acest mecanism cu principiul caracterului personal al răspunderii penale.

\section{O RĂSPUNDERE PENALĂ PERSONALĂ SUI-GENERIS}

De actualitate pentru acest segment analizat este Teoria ficțiunii ${ }^{4}$, aceasta negând posibilitatea ca o persoană juridică să aibă o voință proprie. Astfel, dând aplicare acestei teorii, nu ar fi permisă avansarea la analiza criteriului de tipicitate subiectivă, devenind inutilă orice încercare de tragere la răspundere penală a unei persoane juridice. Deși acest curent de gândire pare acum desuet, necesitatea intervenției Curții Constituționale în pronunțarea asupra unor excepții de neconstituționalitate arată că în continuare există o nesiguranță în aplecarea asupra acestei problematici.

Autoarea uneia dintre excepții este Curtea de Apel Constanța, aceasta fiind ridicată din oficiu asupra dispozițiilor art. 135 din C. pen. coroborate cu cele ale art. 15 C. pen. În motivarea sa, autoarea susține că "forme(le) de vinovăţie prevăzute la art. 16 din Codul

\footnotetext{
${ }^{2}$ M. Of., Partea I, nr. 601 din 12 iulie 2006.

${ }^{3}$ A se vedea José Luis de La Cuesta, Criminal Responsibility of Legal Persons in Spanish Law în Revue internationale de droit pénal 2013/1-2 (Vol. 84), disponibil la adresa https://www.cairn.info/revueinternationale-de-droit-penal-2013-1-page-143.htm\#no32, accesată în data de 31.10.2021. Citatul de referință este "Therefore as Zúñiga Rodríguez expressed, after this reform, the issue in Spanish Law was no longer saying yes or no to the criminal responsibility of legal persons, but accurately deciding "how to implement it" ", în traducere liberă „Prin urmare, astfel cum s-a exprimat Zúñiga Rodríguez, după această reformă problema din dreptul spaniol nu a mai fost acceptarea sau negarea răspunderii penale a persoanei juridice, ci a hotărî implementarea sa corectă".

${ }^{4}$ Pentru mai multe detalii, a se vedea A.-R. Trandafir, Răspunderea penală a persoanei juridice, Ed. C.H. Beck, ediția 2, București, 2021, p. 4.
} 
penal pot fi aplicate numai persoanei fizice, care prezintă trăsăturile proprii fiinţei umane (conştiinţa de sine, voinţă proprie etc.)" 5 . În realitate, ceea ce pare că se ignoră este faptul că persoana juridică este un subiect activ aparte, care nu va putea fi supus niciodată unei analize identice la nivel subiectiv cu cea a persoanei fizice.

Modalitatea de stabilire a formei de vinovăție a persoanei juridice este una care are în vedere realitatea existenței sale, existență care este dată prin suflul uneia sau mai multor persoane fizice. Astfel, reținerile Curții Constituționale sunt în sensul că „răspunderea penală a persoanei juridice reprezintă o ficţiune juridică, expresie a politicii penale a legiuitorului şi în marja de apreciere prevăzută la art. 61 alin. (1) din Constituţie" și că „pentru a face aplicabilă instituţia analizată, legiuitorul a prevăzut în privinţa răspunderii penale a persoanei juridice formele de vinovăţie reglementate la art. 16 din Codul penal, adaptate manierei în care aceasta desfăşoară activităţile şi poate săvârşi fapte de natură penală (...)".

Nu putem nesocoti firescul manifestării persoanei juridice, acestea fiind rezultatul voințelor, intereselor, acțiunilor și inacțiunilor persoanelor fizice care o alcătuiesc. În cercetarea răspunderii penale a acesteia trebuie să înțelegem că, dat fiind modelul direct de răspundere penală a persoanei juridice implementat de legiuitorul nostru, ea nu împrumută nici răspunderea penală, nici forma de vinovăție de la persoana fizică, ci le deține în propria persoană. Analiza celor două componente se realizează având în vedere un cumul de factori, de împrejurări și de voințe ale persoanelor fizice care o manipulează, care îi decid conduita, iar din această multitudine de aspecte reiese o unică concluzie în ceea ce privește persoana juridică, aceasta fiind de fapt răspunderea penală personală a sa, care este totuși o răspundere personală sui-generis.

Spre exemplu, doctrina nu ignoră caracterul aparte al acestui subiect de drept, aspect reliefat de imposibilitatea ca persoana fizică și cea juridică să fie considerate, de regulă, participanți la infracțiunea în cauză ${ }^{6}$, imposibilitate ce rezultă din înțelegerea suprapunerii logice ce are loc.

Curtea reține și faptul că „fiind o ficţiune juridică, latura subiectivă a răspunderii penale a persoanei juridice se realizează, implicit, prin subiectivitatea persoanei care desfăşoară activităţi în numele ei, fiind desemnată în acest sens". Consider că această remarcă trebuie însușită cu o mențiune importantă. Cum persoana juridică nu va căpăta niciodată o independență absolută, forma de vinovăție a acesteia va fi raportată la forma de vinovăție a persoanelor fizice, dar și la circumstanțele proprii ale persoanei juridice, fără ca cele două forme de vinovăție să se confunde și cu posibilitatea ca cele două persoane să răspundă pentru infracțiuni diferite (ex.: omor și ucidere din culpă) ori pentru aceeași infracțiune, însă cu forme de vinovăție distincte.

\section{INDIVIZIBILITATEA RELATIVĂ A CELOR DOUĂ TIPURI DE PERSOANE}

Raportul dintre persoana juridică și persoanele fizice cred că se poate defini prin asemuirea lui cu raportul dintre o mamă și copilul ei. Astfel, deși copilul nu ar fi existat în lipsa existenței mamei și, deși aflat în mod fundamental sub influența acțiunilor și a gândirii

\footnotetext{
${ }^{5}$ A se vedea DCC nr. 302 din 9 iunie 2020 (M .Of., Partea I, nr. 1166 din 2 decembrie 2020). A se vedea în același sens DCC nr. 25 din 19 ianuarie 2021 (M. Of., Partea I, nr. 413 din 20 aprilie 2021), DCC nr. 156 din 27 martie 2018 (M. Of., Partea I, nr. 474 din 8 iunie 2018).

${ }^{6}$ A se vedea A.-R. Trandafir, op. cit., p.398.
} 
mamei, acesta pornește în viață cu o voință proprie. Așadar, și persoana juridică, deși nenăscută în lipsa constituirii persoanelor fizice și organic dependentă de acțiunile acestora din urmă, păstrează totuși o voință proprie.

Spre a exemplifica cele susținute mai devreme în lucrare vom avea în vedere o speță construită în jurul infracțiunii de neluarea măsurilor legale de securitate şi sănătate în muncă ${ }^{7}$. Subiect activ al acesteia poate fi atât persoana juridică, în calitatea sa de angajator, cât și persoana fizică, în calitatea sa de lucrător desemnat. Atunci când societatea dă dovadă de o rigurozitate în luarea măsurilor legale (ex.: desemnează lucrătorii, asigură efectuarea instructajului de securitate și sănătate în muncă angajaților conform legii, cumpără și asigură echipamentul de protecție necesar, etc.), iar lucrătorul desemnat omite să ia măsurile de siguranță pentru a-și însuși anumite foloase materiale (spre exemplu, omite să achiziționeze echipamentele de siguranță necesare pentru o lucrare viitoare, omite să înlocuiască echipamentul de siguranță uzat, vinde componente ale echipamentelor pentru a obține niște bani), identitatea de formă de vinovăție se frânge. Dacă persoana juridică, depunând un minim de diligență în exercitarea supravegherii ar fi putut surprinde neregularitățile recurente pe care un astfel de prepus al său le realiza, cu consecința intervenției acesteia în scopul de a le remedia, atunci i se poate imputa o culpă. Așadar, deși există o conduită infracțională îndreptată chiar împotriva intereselor societății, ce pentru persoana fizică poate lua forma unei infracțiuni cu care cea de la art. 349 C. pen. să intre în concurs, infracțiunea contra siguranței publice este săvârșită în realizarea obiectului de activitate al persoanei juridice, ceea ce permite reținerea răspunderii sale penale.

În sarcina persoanei fizice va fi putea fi reținută infracțiunea de la art. 349 C. pen. în varianta de la alin. (1), sub forma intenției, iar persoanei juridice i se poate reproșa o lipsă de supraveghere, o neglijență (născută de regulă din încrederea în angajații săi și în responsabilitatea cu care aceștia își îndeplinesc atribuțiile date), care duce la reținerea infracțiunii în varianta de la alin. (2), anume sub forma culpei.

Totodată, scindarea se poate face chiar mai devreme, la nivelul existenței răspunderii penale. Astfel, persoana fizică poate fi achitată, iar persoana juridică condamnată. ${ }^{8}$ Se poate ca o persoană fizică responsabilă să nu fie niciodată găsită, însă persoana juridică să fie trasă la răspundere penală.

\section{III. (CON)DAMNAREA PERSOANEI JURIDICE LA O RĂSPUNDERE PENALĂ VEȘNICĂ}

În mod evident, persoana juridică nu va fi condamnată în lipsa îndeplinirii condițiilor prevăzute de lege pentru aceasta ${ }^{9}$. Trebuie atrasă atenția asupra faptului că, atunci când analiza ajunge la nivelul laturii subiective, posibilitatea ca persoana juridică să fi acționat fără vinovăție se reține în cazuri excepționale. Pe umerii săi atârnă foarte multe

\footnotetext{
${ }^{7}$ Potrivit art. 349 C. pen. „(1) Neluarea vreuneia dintre măsurile legale de securitate şi sănătate în muncă de către persoana care avea îndatorirea de a lua aceste măsuri, dacă se creează un pericol iminent de producere a unui accident de muncă sau de îmbolnăvire profesională, se pedepseşte cu închisoare de la 6 luni la 3 ani sau cu amendă. (2) Fapta prevăzută în alin. (1) săvârşită din culpă se pedepseşte cu închisoare de la 3 luni la un an sau cu amendă".

${ }^{8}$ A se vedea Curtea de Apel Cluj, decizia nr. 982/2021 din 7 iulie 2021 (www.rolii.ro). Persoana juridică a fost condamnată pentru infracțiunea de neluarea măsurilor legale de securitate și sănătate în muncă, săvârșită cu intenție, iar administratorul a fost achitat în temeiul art. 16 alin. (1) lit. c) C. proc. pen.

${ }^{9}$ Potrivit art. 396 alin. (2) C. proc. pen. „Condamnarea se pronunță dacă instanța constată, dincolo de orice îndoială rezonabilă, că fapta există, constituie infracțiune și a fost săvârșită de inculpat".
} 
responsabilități, ceea ce face adesea ca desfășurarea activității sale să nu fie întotdeauna într-o perfectă consonanță cu legea. Așadar, deși nu îi poate fi reproșată o intenție, de cele mai multe ori îi poate fi reproșată o neglijență.

Societățile sunt structuri piramidale în interiorul cărora pot apărea diverse nereguli, acestea fiind situate pe două grade de intensitate. Există cele ce nu sunt de natură a afecta echilibrul piramidei, acest caz coincizând cu reținerea unei lipse de vinovăție a persoanei juridice, întrucât activitatea infracțională ce se desfășoară în legătură cu aceasta este atât de obscură și de atent camuflată, dând aparența îndeplinirii exacte a atribuțiilor de către fiecare persoană fizică, încât chiar cu depunerea tuturor diligențelor de către societate, aceasta nu putea fi descoperită. Al doilea tip de nereguli este reprezentat de cele ce duc la clătinarea societății, aspect ce nu mai poate fi tolerat și ce impune luarea de măsuri pentru restabilirea echilibrului, acestea fiind cazurile în care activitatea infracțională a putut fi desfășurată dintr-o insuficientă lipsă de supraveghere și de control din partea persoanei juridice.

Este o situație ușor capricioasă pentru că deși o societate funcționează pe baza unui sistem de cumul de forțe umane, unde premisa este că activitatea se desfășoară eficient deoarece fiecare își duce la îndeplinire atribuțiile exact așa cum i-au fost conferite, totuși corecta desfășurare a activității sale nu se poate axa exclusiv pe o încredere deplină, îndepărtându-se nevoia de supraveghere, nevoie ce, în realitate, instituie consecințe juridice pentru societate.

Pentru a ilustra problematica lipsei de supraveghere și de control ce poate lua forma cuplei, pot fi avute în vedere dispozițiile din Legea 319/2006 a securităţii si sănătăţii în muncă ${ }^{10}$.

O societate se constituie prin alăturarea puterilor mai multor persoane fizice, în scopul realizării unor activități ce devin profitabile prin buna coordonare a muncii lor. Această colectivitate creată trebuie să fie ocrotită ea însăși, dar trebuie să ocrotească și persoanele ce gravitează sub o formă sau alta în jurul ei, fiind astfel responsabilă de ducerea la îndeplinire a unui număr vast de obligații. Această respectare a obligațiilor poate fi asigurată prin propriile forțe ale societății, ori prin intrarea în relații contractuale cu persoane specializate în anumite domenii. Răspunderea penală însă își poate păstra actualitatea chiar în situația delegării obligațiilor.

Așadar, angajatorul este cel care rămâne întotdeauna responsabil pentru luarea măsurilor ce privesc securitatea și sănătatea în muncă, chiar dacă apelează la serviciile unei alte persoane în acest sens ${ }^{11}$.

Pentru reținerea formei de vinovăție a intenției este necesar ca persoana juridică să fi avut o atitudine de toleranță, de acceptare sau chiar de încurajare a practicilor desfășurate în disprețul legii, pe când pentru reținerea culpei este necesar să se probeze „că la nivelul persoanei juridice mecanismele ei interne au fost deficitare"12. În domeniul supus analizei se găsesc aproape întotdeauna măsuri legale care nu au fost luate de către persoana juridică, ceea ce greu permite existența unor situații în care să nu i se impute nicio vină. Astfel cum s-a menționat în doctrină, „în virtutea obligației de diligență, a verificărilor efectuate și a exercitării controlului ierarhic în cadrul unei persoane juridice, conducerii nu îi

\footnotetext{
${ }^{10}$ M. Of., Partea I, nr. 646 din 26 iulie 2006.

11 Potrivit art. 6 alin. (2) din Legea nr. 139/2006 „în cazul în care un angajator apelează la servicii externe, acesta nu este exonerat de responsabilităţile sale în acest domeniu".

${ }^{12}$ A se vedea, în acest sens, A.-R. Trandafir, op.cit., p. 284-285.
} 
este permis decât în mod excepțional să nu aibă cunoștință despre o conduită ilicită săvârșită în desfășurarea activității." ${ }^{13}$

Există astfel o obligație permanentă a angajatorului de supraveghere a ducerii la îndeplinire de către contractantul său a măsurilor legale de securitate și sănătate în muncă și, implicit, o permanentă obligație de a lua măsurile respective chiar el însuși, sub amenințarea reținerii în sarcina sa a infracțiunii prevăzute de art. 349 C. pen. ${ }^{14}$

Spre exemplu, în C. pen. spaniol este reglementată expres răspunderea penală a persoanei juridice pentru infracțiunile care au fost realizate în exercitarea activității sale, în numele și în beneficiul său direct ori indirect de către cei care, fiind supuși autorității reprezentanților legali sau a administratorilor, fie de fapt ori de drept, au săvârșit infracțiunea prin încălcarea gravă de către aceștia din urmă a îndatoririlor corespunzătoare de control, ținând cont de circumstanțele specifice ale cauzei ${ }^{15}$. Această situație se prezintă în practica noastră ca o formă a culpei.

De pildă, considerentele avute în vedere de către o instanță pentru condamnarea unei societăți care avea ca obiect de activitate distribuția de gaz pentru infracțiunea de distrugere din culpă au fost următoarele „în prezenta cauză se constată, în ceea ce priveşte persoana juridică, un viciu de organizare, un deficit de control asupra angajaţilor proprii cu atribuţii de execuţie şi anume asupra inculpaţilor din prezenta cauză, persoane fizice, ce a condus în final, ca urmare a conduitei acestora la care s-a referit mai sus, la producerea deflagraţiei şi urmările menţionate” Persoana juridică a susținut în favoarea sa faptul că „nu poate fi considerată responsabilă din punct de vedere penal pentru eventualele îndepliniri necorespunzătoare a atribuţiilor de serviciu de către angajaţi atât timp cât (...) a respectat toate obligaţiile prevăzute de normativele în vigoare şi a implementat un sistem complet de pârghii de control de raportare şi de verificare la fiecare nivel decizional"16.

Deși argumentul acesteia este unul bun pentru a o pune la adăpost de reținerea altor infracțiuni care intră de regulă un concurs cu infracțiunile de rezultat ${ }^{17}$, acesta nu a fost un argument suficient pentru a îndepărta răspunderea persoanei juridice pentru lipsă de vinovăție în primă instanță.

Sentința a fost apelată, iar Curtea de Apel a achitat în fine societatea, reținând că ,în cazul de faţă nu se relevă astfel de deficiențe - organizări defectuoase, lipsa unui control al angajaţilor, lipsa aparaturii, instalaţiilor adecvate şi necesar e acestei activităţi, etc. şi ceea ce este mai important, în actul de sesizare nu s-a făcut trimitere la o acţiune/inacţiune culpabilă a persoanei juridice de genul celor amintite ci s-a reţinut doar existenţa culpei

\footnotetext{
${ }^{13}$ A se vedea G.-A. Lazăr, Criteriile de evaluare a vinovăției persoanei juridice, în Analele Universității București - Seria Drept, 2019, p. 156.

${ }^{14}$ A se vedea $D$. Herinean, Considerații teoretice privind formarea legăturii subiective în cazul răspunderii penale a persoanelor juridice, în Analele Universității București - Seria Drept, 2019, p. 137. Autorul punctează faptul că în astfel de cazuri „persoanelor juridice le este imputată de fapt o conduită anterioară săvârșirii unei infracțiuni, iar nu o conduită concomitentă cu săvârșirea materială a infracțiunii".

15 Art. 31 bis $^{1}$ C. pen. spaniol, disponibil în limba engleză la adresa https://www.legislationline.org/download/id/6443/file/Spain CC am2013 en.pdf, accesată în data de 31 octombrie 2021.

${ }^{16}$ A se vedea Jud. Bacău, sentința nr. 1943/2015 din 23 decembrie 2015 (www.rolii.ro).

17 Neluarea măsurilor legale de securitate și sănătate în muncă (art. 349 C. pen) și nerespectarea măsurilor legale de securitate și sănătate în muncă (art. 350 C. pen).
} 
persoanelor fizice angajaţi ai acesteia apreciată ca fiind suficientă pentru a atrage răspunderea penală (a societății)"18.

Așadar, asupra persoanei juridice atârnă întotdeauna sabia lui Damocles ${ }^{19}$, având în vedere amplele sale responsabilități pe care aceasta le poate duce la îndeplinire în mod corect doar prin crearea unui sistem de organizare responsabil, funcțional și competent care sa oglindească interesul și efortul depuse de aceasta în desfășurarea activității sale. Acesta consider că trebuie să fie și standardul de apreciere în momentul analizei existenței ori inexistenței unei forme de vinovăție în sarcina sa, căci dacă neregulile sunt nesemnificative, ori arată o scăpare, un comportament izolat și întâmplător, ori se află chiar în afara sferei de control a persoanei juridice, atunci acesteia nu îi poate fi reținută nicio vină. Dacă însă neajunsurile la nivelul societății puteau fi prevenite prin instituirea unui sistem de organizare complet, printr-o minimă supraveghere sau alte eforturi rezonabile din partea societății, atunci se pătrunde deja în sfera culpei.

De altfel, există un alt grad de intensitate pentru analiza problematicii atunci când aceasta cade pe cumpăna dintre forma de vinovăție a culpei cu prevedere și cea a intenției indirecte. În acest sens a fost reținut argumentul că este insuficient ca societatea să își fi organizat activitatea pe departamente astfel încât mai multe persoane să exercite anumite activități în legătură cu securitatea și sănătatea în muncă (inspector de securitate și sănătate în muncă, director tehnic) și să se fi bazat pe ducerea la îndeplinire de către acestea a sarcinilor sale, întrucât „elementele obiective asupra cărora putea să se bazeze societatea inculpată pentru a aprecia că urmarea nu se va produce nu pot fi tocmai persoanele care au aptitudinea de a angaja răspunderea penală a societăţii"20. Ca o mențiune, această sintagmă de a „angaja răspunderea penală a persoanei juridice” poate fi văzută ca fiind improprie deoarece, în realitate, aceste persoane atrag doar atenția asupra vocației persoanei juridice de a răspunde pentru fapta proprie, iar nu pentru fapta lor, chiar dacă există identitate materială.

Consider totuși că o abordare mai pragmatică a preocupării menționate mai sus este cea de înclinare asupra formei de vinovăție a culpei. Un aspect important de avut în vedere este și cel al mărimii societății și al posibilității sale reale de a efectua supravegherea asupra procesului de muncă, în cazul de față. Se impune a se descoperi o atitudine de neglijență extremă care să se confunde chiar cu o toleranță a desfășurării activităților în disprețul standardelor impuse de lege pentru a putea afirma că societatea a prevăzut rezultatul faptei sale și, deși nu l-a urmărit, a acceptat posibilitatea producerii lui.

În fine, pentru a ilustra posibilitatea excepțională de reținere a lipsei de vinovăție, învederez o speță referitoare la infracțiuni la regimul silvic, unde obiectul judecății îl reprezintă infracțiuni ce pot fi săvârșite numai cu intenție (formă de vinovăție rar ori neglijent reținută, fiind dificil de probat în cazul persoanelor juridice), instanța reține ca linie generală de reflecție că „vinovăția persoanei juridice este determinată de măsura în care modul de organizare sau funcţionare al acesteia a determinat comiterea infracţiunii"21. Coordonatele speței sunt că prepușii societății au acționat, așa cum reține instanța, din

\footnotetext{
${ }^{18}$ A se vedea Curtea de Apel Bacău, decizia nr. 1294/2016 din 29 noiembrie 2016, definitivă (www.rolii.ro), unde persoana juridică a fost achitată în temeiul prevăzut de art. 16 alin. (1) lit. b), teza a II-a C. proc. pen.

${ }^{19}$ Cunoscută anecdotă din cultura greacă, poate fi consultată la adresa https://ro.wikipedia.org/wiki/Damocles\#Sabia lui Damocles.

${ }^{20}$ A se vedea, Curtea de Apel Cluj, decizia nr. 982/2021 din 7 iulie 2021, definitivă (www.rolii.ro).

${ }^{21}$ A se vedea Jud. Zărnești, s.p. nr. 167 din 26 mai 2021 (www.rolii.ro), în A.-R. Trandafir, op. cit., p. 286.
} 
eroare asupra tipicității faptei, iar organele de conducere nu știau despre săvârșirea infracțiunii. Astfel, atât prepușii, cât și societatea au fost achitați în baza art. 16 alin. (1) lit. b) teza a II-a C. proc. pen.

\section{CONCLUZII}

În practica judiciară am identificat două curente, unul mai vechi, care se manifesta prin omisiunea de a încerca tragerea la răspundere penală a persoanei juridice, deși situația oferea indicii clare în acest sens, și un curent nou, de a trage la răspundere penală persoana juridică fără a exista o analiză completă și aflată în directă legătură cu aceasta.

La societățile mici voința persoanei juridice și cea a peroanelor fizice tinde să ia aceeași formă, aspect care nu este nicicum greșit, însă latura subiectivă trebuie alăturată unei acțiuni proprii pentru fiecare persoană (spre exemplu, persoana juridică nu a achiziționat echipamente de protecție, iar persoana fizică a demarat activitatea de muncă chiar în lipsa acestora) iar la societățile mari, deși în virtutea dimensiunii lor, acestea ori organele de conducere sau de administrare pot răspunde mai blând față de persoana fizică executantă, de exemplu, sau pot chiar să nu răspundă, situația unei răspunderi mai ușoare sau a lipsei acesteia nu va fi neapărat întâlnită22.

Așadar, dacă o persoană juridică de mari dimensiuni creează un sistem organizatoric apt să realizeze atribuții de supraveghere și de control la toate nivelurile sale, fără a-și abandona propriile atribuții de această natură, respectă obligațiile impuse de lege în sarcina sa cu o regularitate ce poate demonstra o conștiinciozitate în felul în care aceasta înțelege să își desfășoare activitatea, iar momentul fatidic are loc în ciuda eforturilor depuse de aceasta, consider că nu i se poate imputa vreo vină. În schimb, în momentul în care chiar persoanele cu atribuții de control și supraveghere încep să adopte o atitudine contrară valorilor societății, iar aceasta neglijează să le supravegheze și să le controleze la rândul ei, atunci poate interveni culpa sa. Nu vorbim totuși despre o obligație draconică, ci despre una analizată la un standard aflat peste un nivel rezonabil, proprie unui profesionist.

\footnotetext{
${ }^{22}$ A se vedea Curtea de Apel Cluj, op. cit., "Instanţa a constatat, contrar apărărilor formulate în cauză, că inclusiv administratorul unei societăţi mari sau chiar a unei multinaţionale, poate să răspundă penal în temeiul art. 349 alin. 1 C.pen., nefiind exceptat în acest sens, ci, dimpotrivă, art. 6 din Legea nr. 319/2006 stabileşte în mod expres răspunderea prioritară a angajatorului".
} 